NBER WORKING PAPER SERIES

\title{
SCHUMPETERIAN PROFITS IN THE AMERICAN ECONOMY: THEORY AND MEASUREMENT
}

\author{
William D. Nordhaus \\ Working Paper 10433 \\ http://www.nber.org/papers/w10433
NATIONAL BUREAU OF ECONOMIC RESEARCH 1050 Massachusetts Avenue
Cambridge, MA 02138
April 2004

The views expressed herein are those of the author(s) and not necessarily those of the National Bureau of Economic Research.

(C2004 by William D. Nordhaus. All rights reserved. Short sections of text, not to exceed two paragraphs, may be quoted without explicit permission provided that full credit, including $(\mathcal{C}$ notice, is given to the source. 
Schumpeterian Profits in the American Economy: Theory and Measurement

William D. Nordhaus

NBER Working Paper No. 10433

April 2004

JEL No. O30, O31, O4

\section{ABSTRACT}

The present study examines the importance of Schumpeterian profits in the United States economy. Schumpeterian profits are defined as those profits that arise when firms are able to appropriate the returns from innovative activity. We first show the underlying equations for Schumpeterian profits. We then estimate the value of these profits for the non-farm business economy. We conclude that only a miniscule fraction of the social returns from technological advances over the 1948-2001 period was captured by producers, indicating that most of the benefits of technological change are passed on to consumers rather than captured by producers.

William D. Nordhaus

Yale University, Department of Economics

28 Hillhouse Avenue

Box 208264

New Haven, CT 06520-8264

and NBER

william.nordhaus@yale.edu 
The United States economy has benefited from rapid technological change over the last decade. The present study inquires into the fraction of the benefits from new technologies that have been captured by innovators (these being Schumpeterian profits) as compared to the fraction that have been passed on in lower prices.

The question of the appropriability of technological change is important for several reasons. First, we want to understand the role of innovational profits in total profits. Second, investors want to understand the importance of innovation in stock-market returns. Third, to the extent that innovation leads to higher wealth, there is a wealth effect of technological change on aggregate demand (this being the "Greenspan effect" posited by Fed chairman Alan Greenspan). This study examines each of these phenomena.

\section{A Model of Appropriability and Schumpeterian Profits}

\section{A. Background}

Endogenous growth theory, along with the theory of induced innovation, has developed important new approaches to understanding the role of innovation in economic growth. Joseph Schumpeter introduced modern approaches in his pathbreaking book, The Theory of Economic Development. ${ }^{1}$ The formal theory of induced innovation arose in the 1960s in an attempt to understand why technological change appears

1 Theorie der wirtschaftlichen Entwicklung, variously dated as 1911 or 1912, available currently in translation published by Transaction Books, New Brunswick, N.J., 1983. 
to have been largely labor saving. ${ }^{2}$ More recently, theories of induced technological change were revived as the new growth theory, pioneered by Robert Lucas and Paul Romer. ${ }^{3}$ This has blossomed into a major research field, with a wide variety of theories and applications. ${ }^{4}$

Virtually all studies of induced innovation have been theoretical. With few exceptions, they do not lay out a set of testable hypotheses or ones that can be used to model the innovation process at an industrial level. There are to my knowledge no estimates of total Schumpeterian profits by industry or for the entire economy.

The underlying idea to be developed in this section is straightforward. Numerous individuals and firms in a modern economy are engaged in innovative activities designed to produce new and improved goods and services along with processes that reduce the cost of production. Some of these are formalized in legal ownership of intellectual property rights such as patents, copyrights, and trademarks, while others are no more than trade secrets or early-mover advantages.

\footnotetext{
2 See Richard Nelson, "The Simple Economics of Basic Scientific Research," Journal of Political Economy, vol. 67, 1959, pp. 297-306, and Kenneth Arrow, "Economic Welfare and the Allocation of Resources for Invention," in Richard Nelson, The Rate and Direction of Inventive Activity, Princeton University Press for National Bureau of Economic Research, 1962, pp. 609625.
}

3 See Robert E. Lucas, "On the Mechanics of Economic Development," Journal of Monetary Economics, January 1988, pp. 3-32, and Paul Romer, "Endogenous Technological Change," Journal of Political Economy, vol. 98, October 1990, No. 5, Part 2, pp. S71-S102.

${ }^{4}$ A comprehensive survey is provided in Philippe Aghion and Peter Howitt, Endogenous Growth Theory, MIT Press, Cambridge, Mass., 1997. 
Some of the innovative activities produce extra-normal profits (called Schumpeterian profits), which are profits above those that would represent the normal return to investment and risk-taking.

In this study, we take a slightly restrictive definition of Schumpeterian profits. These comprise only the profits that exceed the risk-adjusted return to innovative investments. In other words, any research and development (R\&D) that yields a normal return on investment will lead to an increase in output or decrease in inputs but no increase in appropriately measured ${ }^{5}$ multifactor productivity (MFP).

Most of the innovations produce social value as well as private value. When copy machines replace scribes, or computers replace hand calculations, the social cost of producing a given amount of goods and services declines. It is well established that innovators do not generally capture the entire social value of inventive and innovational activity. ${ }^{6}$

${ }^{5}$ Because of U.S. accounting conventions, R\&D is treated as a current rather than a capital expense and will distort measures of MFP growth. Additionally, some R\&D is devoted to new products, which may not be captured in price indexes; this factor will probably underestimate MFP growth.

6 There is a vast literature discussing the relationship between social and private returns to innovation. See Zvi Griliches, "Research Expenditures and Growth Accounting," in M. Brown, ed., Science and Technology in Economic Growth, New York, Wiley, 1973; Zvi Griliches, "Productivity, R\&D, and Basic Research at the Firm Level in the 1970s," American Economic Review, vol. 76, 1986, pp. 141-54; Bronwyn Hall, "The Private and Social Returns to Research and Development," in Bruce Smith and Claude Barfield, Technology, RED, and the Economy, Brookings, 1995, pp. 140-183; Adam Jaffe, "Technological Opportunity and Spillover of R\&D: Evidence from Firms' Patents, Profits, and Market Value," American Economic Review, vol. 76, 1986, pp. 984-1001; Adam Jaffe, Manuel Trajenberg, and Rebecca Henderson, "Geographical Localization of Knowledge Spillovers as evidence by Patent Citations," Quarterly Journal of Economics, 1993; Richard 
To a first approximation, it is generally believed, most of the value of new products and processes are eventually passed on to consumers in the form of lower prices of goods and services. But not all, and not immediately. Often, inventors and innovators get at least a slice of the social returns to productivity growth. Although there is scattered evidence that the degree of appropriability varies greatly across industries, there is little evidence on the size of the slice that goes to the originators of technological change and no evidence on the size of Schumpeterian profits for the entire economy. Some industries like pharmaceuticals have high rates of profit and appear to capture a substantial fraction of the value of new products during (and sometimes after!) the patent lifetimes. Other industries, such as farming, are ones, which have enjoyed very rapid productivity growth without a corresponding high profitability of farmers or farm-equipment manufacturers.

Levin, Alvin Klevorick, Richard Nelson, and Sidney Winter, "Appropriating the Returns from Industrial Research and Development," Brookings Papers on Economic Activity, no. 3, 1987, pp. 783- 820; Edwin Mansfield, "Social and Private Rates of Return from Industrial Innovations," Quarterly Journal of Economics, 1977, vol. 91, pp. 221-40, "Basic Research and Productivity Increase in Manufacturing," American Economic Review, vol. 70, 1980, pp. 863-873, “How Fast Does New Industrial Technology Leak Out?" Journal of Industrial Economics, vol. 34, 1985, pp. 217223, "Macroeconomic Policy and Technological Change," in Jeffrey C. Fuhrer and Jane Sneddon Little, eds, Technology and Growth, Conference Proceedings, Federal Reserve Bank of Boston, 1996, pp. 183-200; Edwin Mansfield et al., Social and Private Rates of Return from Industrial Innovations, 1995, NTIS, Washington, D. C.; and Nathan Associates, Net Rates of Return on Innovation, Report to the National Science Foundation, 1978. 


\section{B. A Two-Period Model}

We can formalize these issues as follows. The model that follows is just a sketch of how innovational profits arise. There is no attempt to derive this from first microeconomic principles as that would probably either impose unrealistic limitations on the assumptions or produce untestable implications.

The basic assumption is that there is a stream of innovations in an industry, which lead to a more or less continuous reduction in the cost of production, $c_{t}$, for firm or industry i (I suppress the notation that this refers to industry i where inessential). Some of the innovations are in the public domain, such as the availability of improved weather forecasts. These are inappropriable and are therefore passed on in lower costs and prices of goods or services. Other cost reductions are at least partially appropriable by the producers in the industry and are only partially passed on in price reductions. For those innovations whose cost reductions are partially appropriated, the producers or innovators will have temporary increases in profits, which are labeled Schumpeterian profits.

The two-period version of this model will illustrate the basic points. Consider a perfectly competitive industry where the technology is constant returns to scale. The level of productivity is represented by $A_{t}$, and the cost of production is $C_{t}=k A_{t}$, where $k$ is a constant. In period 0 , the dominant technology is widely available and determines the market price. The dominant technology has cost $C_{0}$ and the good has a market price of $P_{0}=\mathrm{C}_{0}$. 
A new innovation arrives in period 1 and lowers production cost to $C_{1}<C_{0}$. Assume that the inventor can appropriate the fraction $a$ of the cost savings from the innovation; $a$ is the fundamental appropriability ratio, which will be estimated below. Then for small innovations, the inventor maximizes profit by setting the price at $P_{1}=C_{1}+a\left(C_{0}-C_{1}\right)$. Figure 1 shows the initial competitive price, new cost, and new price under these assumptions. The shaded profit region is Schumpeterian profits. As is shown in Figure 1, the second-period price $\left(P_{1}\right)$ lies between competitive cost of the old technology $\left(C_{0}\right)$ and the new lower cost of the innovation $\left(C_{1}\right)$. The extent to which $P_{1}$ is above the $C_{1}$ depends upon the appropriability ratio. 


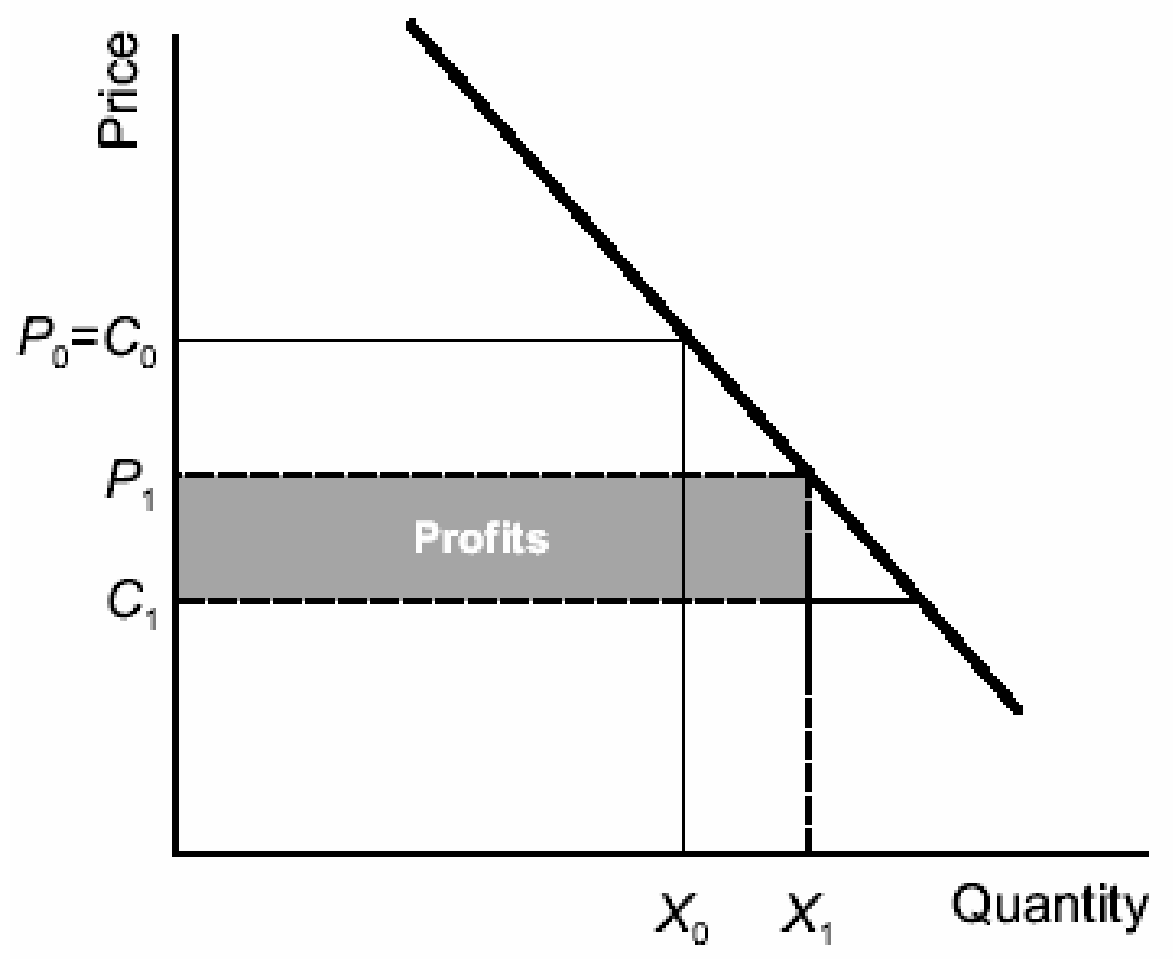

Figure 1. Technological Change and Schumpeterian Profits

The shaded region shows the Schumpeterian profits, while social surplus is the quadrilateral bounded by the $P_{0}=C_{0}$ line, the demand curve, the $C_{1}$ line and the vertical axis. The ratio of Schumpeterian profits to social gains is determined by the appropriability ratio. 
The inventor's profits are equal to $\left(P_{1}-C_{1}\right) X_{1}$, which can be approximated by $a\left(C_{0}-C_{1}\right) X_{0}=a\left[\left(C_{0}-C_{1}\right) / C_{0}\right]\left(P_{0} X_{0}\right)=a\left(\Delta A_{1} / A_{0}\right) Q_{0}$, where $Q_{t}=P_{t} X_{t}$ is nominal output. In words, the private value of the innovation to the innovator is approximately equal to the appropriability ratio times the rate of improvement in technology times the nominal value of output.

To put this theory in a dynamic framework, we need to take into account the erosion of Schumpeterian profits over time. These temporary profits decay because of such factors as the expiration or nonenforcement of patents, the ability of others to imitate or innovate around innovations, the introduction of superior goods and services, and the loss of first-mover advantages. I will model the erosion of Schumpeterian profits as a simple exponential-decay process with decay rate $\lambda$ per year. This implies that if an innovation was introduced $\theta$ years ago, the appropriation rate would be $a e^{-\lambda \theta}$ at the end of $\theta$ years. Finally, to simplify the analysis, I assume for this exposition that prices and costs are normalized so that the cost of inputs is always 1 . This implies that any reduction in costs is due only to productivity growth.

\section{A Multi-Period Model}

Using the framework just introduced, this implies that if there were only one innovation, which occurs in period $(t-\theta)$, current price would be:

$$
P_{t}=C_{t}-a e^{-\lambda \theta}\left(C_{t}-C_{t-\theta}\right) .
$$

Here, $a$ is the first-period appropriability of innovations, while the appropriability $\theta$ periods after the innovation is $a e^{-\lambda \theta}$. If the stream of 
innovations is continuous, then current price would be determined by the past innovations and the extent to which Schumpeterian profits had eroded. Because an innovation $\theta$ periods ago yielded a cost improvement of $\dot{C}_{t-\theta}$, we can integrate all the cost improvements over time to obtain the complete version of (1):

(2) $\quad P_{t}=C_{t}-\int_{0}^{\infty} a e^{-\lambda \theta} \dot{C}_{t-\theta} d \theta$.

The integral on the right hand side of (2) is the accumulated Schumpeterian profits, which I define as $S_{t}$ :

(3) $S_{t}=\int_{0}^{\infty}-a e^{-\lambda \theta} \dot{C}_{t-\theta} d \theta$.

Note that since costs are falling over time, $S_{t}$ is positive.

Finally, note that if the rate of productivity growth is constant at $h^{*}$ per year, then (2) and (3) simplify to:

$$
\left(P_{t}-C_{t}\right) / C_{t}=\int_{0}^{\infty}-a e^{-\lambda \theta}\left[\dot{C}_{t-\theta} / C_{t}\right] d \theta=a h^{*} /\left(\lambda-h^{*}\right)
$$

We define $\mu_{t}$ as the Schumpeterian profit margin. The equilibrium Schumpeterian profit margin is equal to the appropriability ratio times a dynamic factor that equals the ratio of the rate of productivity growth divided by the difference between the rate of decay of Schumpeterian profits and the rate of productivity growth. The upper limit on the rate of 
profit is the appropriability factor, but this upper limit gets diluted by the evaporation of Schumpeterian profits.

Define the profit margin as $\mu_{t}=\left(P_{t}-C_{t}\right) / C_{t}$. Then take the time derivative of the markup and use equations (2) and (3), which yields

$$
\dot{\mu}_{t-\theta} C_{t}+\dot{C}_{t} \mu_{t}=d\left[\int_{0}^{\infty}-a e^{-\lambda \theta} \dot{C}_{t-\theta} d \theta\right] / d t=-\lambda S_{t}-a \dot{C}_{t}
$$

Since $\dot{C}_{t-\theta} / C_{t}=-h_{t}$, this reduces to

$$
\dot{\mu}_{t-\theta}=\left(a+\mu_{t}\right) h_{t}-\lambda \mu_{t}
$$

In steady state, where $\mu_{t}$ and $h_{t}$ are constant at $\mu^{*}$ and $h^{*}$, this reduces to

$$
\mu^{*}=a h^{*} /\left(\lambda-h^{*}\right)
$$

which is identical to equation (4).

We can also derive equation (5) in difference form, which yields

$$
\mu_{t}=(1-\lambda) \mu_{t-1}+a h_{t}+\mu_{t-1} h_{t}
$$

The major coefficients of interest are $\lambda$, which is the rate of depreciation of Schumpeterian profits, and $a$, which is the Schumpeterian appropriation ratio. 
Equations (6) and (7) are two alternative representations of the relationship between the Schumpeterian profit margin and the rate of technological progress. Equation (6) would be appropriate in circumstances where the industry was in "innovational steady state" that is, where the rate of innovation was more or less constant. Equation (7) would be appropriate where the rate of technological change were changing, such as occurred in the new economy over the last decade.

\section{A Multi-Period Calibrated Model}

We can illustrate the model here using a calibrated model of innovation. For this purpose, I assume follow the model described in the last section. Invention is assumed to be uncertain and follow a beta distribution with parameters $(3, .3)$ :

$h_{t}$ is distributed as $.02 \beta(3, .3)$

This produces a median annual productivity growth of 0.3 percent per year and a standard deviation of around 10 percent per year. Multifactor productivity of the low-cost producer is equal to $h_{t}$. The other parameters are:

$$
\begin{aligned}
& a=\text { appropriability factor }=0.2 \\
& \lambda=\text { depreciation rate }=0.08 \text { per year }
\end{aligned}
$$

Figures 2 and 3 show a typical simulation of the system. Figure 2 shows the monopoly cost as the solid line as well as the market price with + marks. The market price is always higher than the monopoly price 
because of partial appropriability. Additionally, when there is little innovation (as between period 27 and 37), the price-cost margin tends to shrink as the Schumpeterian margin depreciates.

Figure 3 shows the Schumpeterian margin, defined as the ratio $\gamma=$ (market price - monopoly cost)/market price. This margin shoots up after a major invention, and then declines as Schumpeterian profits dissipate. From equation (6), the theoretical average Schumpeterian margin is

$$
\mu^{*}=a h^{*} /\left(\lambda-h^{*}\right)=0.2 .018 /(.08-.018)=5.8 \text { percent, }
$$

whereas the average from the simulation shown in Figure 3 is 4.3 percent. The difference is due to the non-linearity of the margin equation.

Figure 4 compares the price trajectories of two simulations with the same underlying technological shocks but with different appropriability ratios, while Figure 5 shows the associated profit margins. For the high appropriability ratio of 0.5 , the Schumpeterian margin is higher as actual price tends to remain above the monopoly cost while with the lower appropriability ratio of 0.5 there is little daylight between monopoly cost and price. 


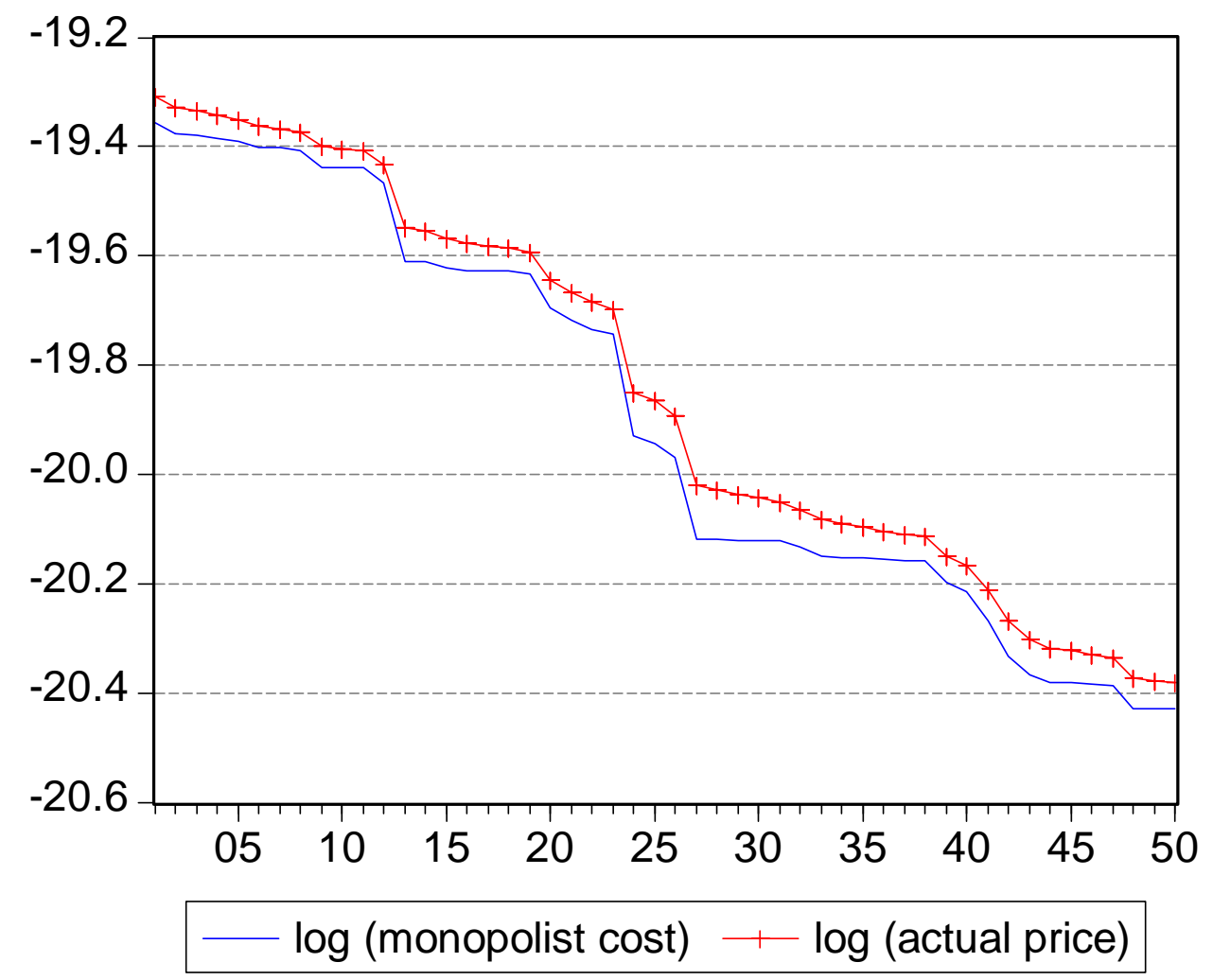

Figure 2. Simulation of cost and price in Schumpeterian model $(n=50)$ 


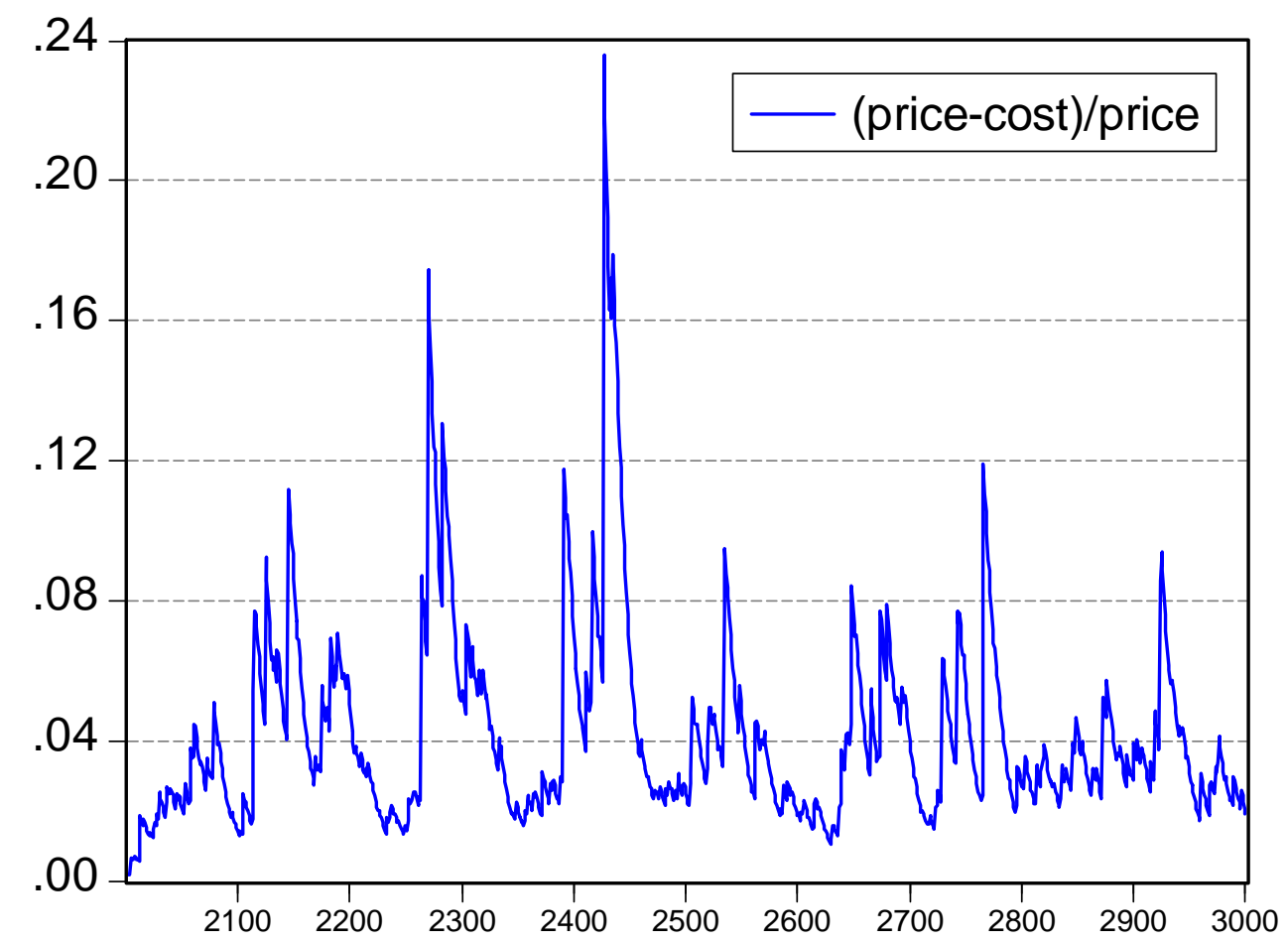

Figure 3. Simulation Schumpeterian profit margin $(n=1000)$ 


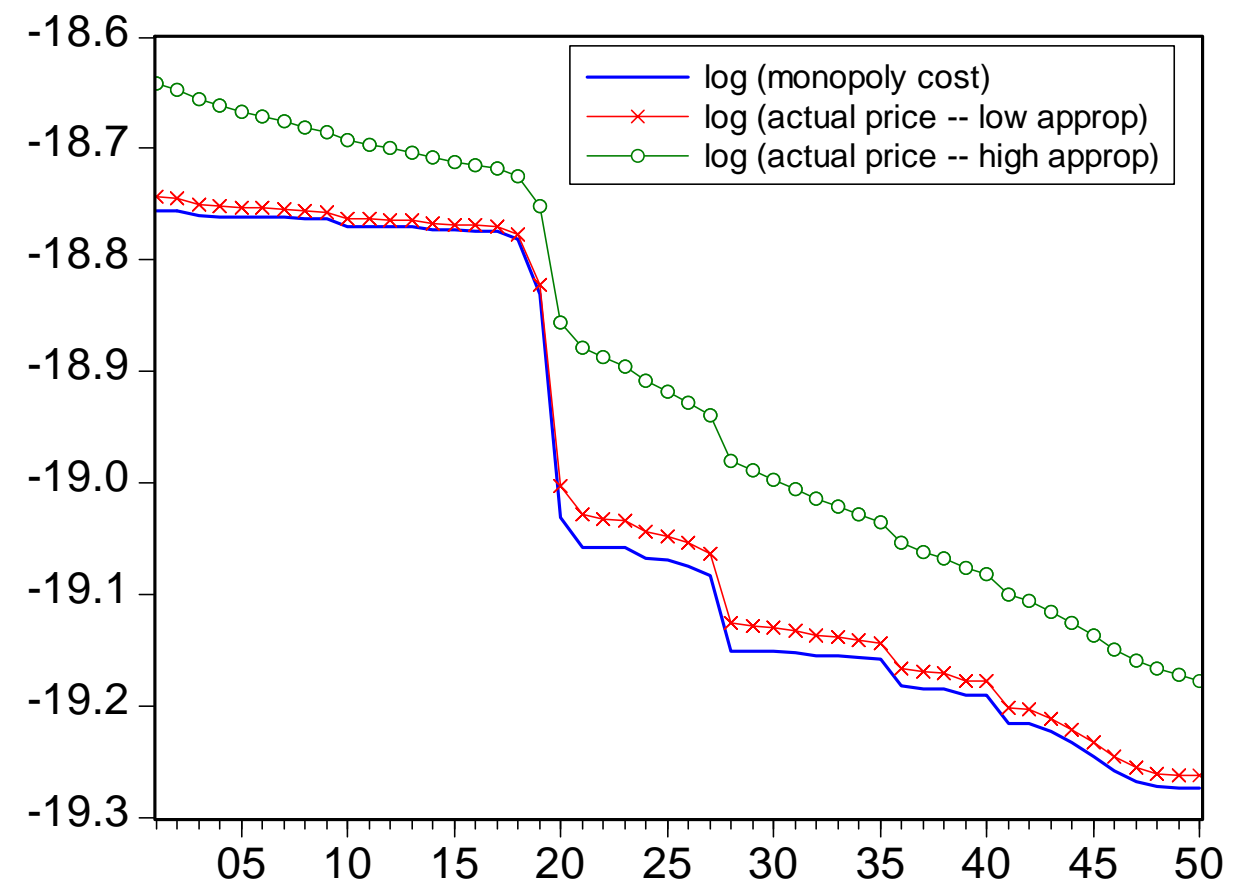

Figure 4. Price trajectories under low and high appropriability $(n=50)$

(Upper line (o) has appropriability factor of 0.5 while lower line $(\mathrm{x})$ has appropriability factor of 0.1 ) 


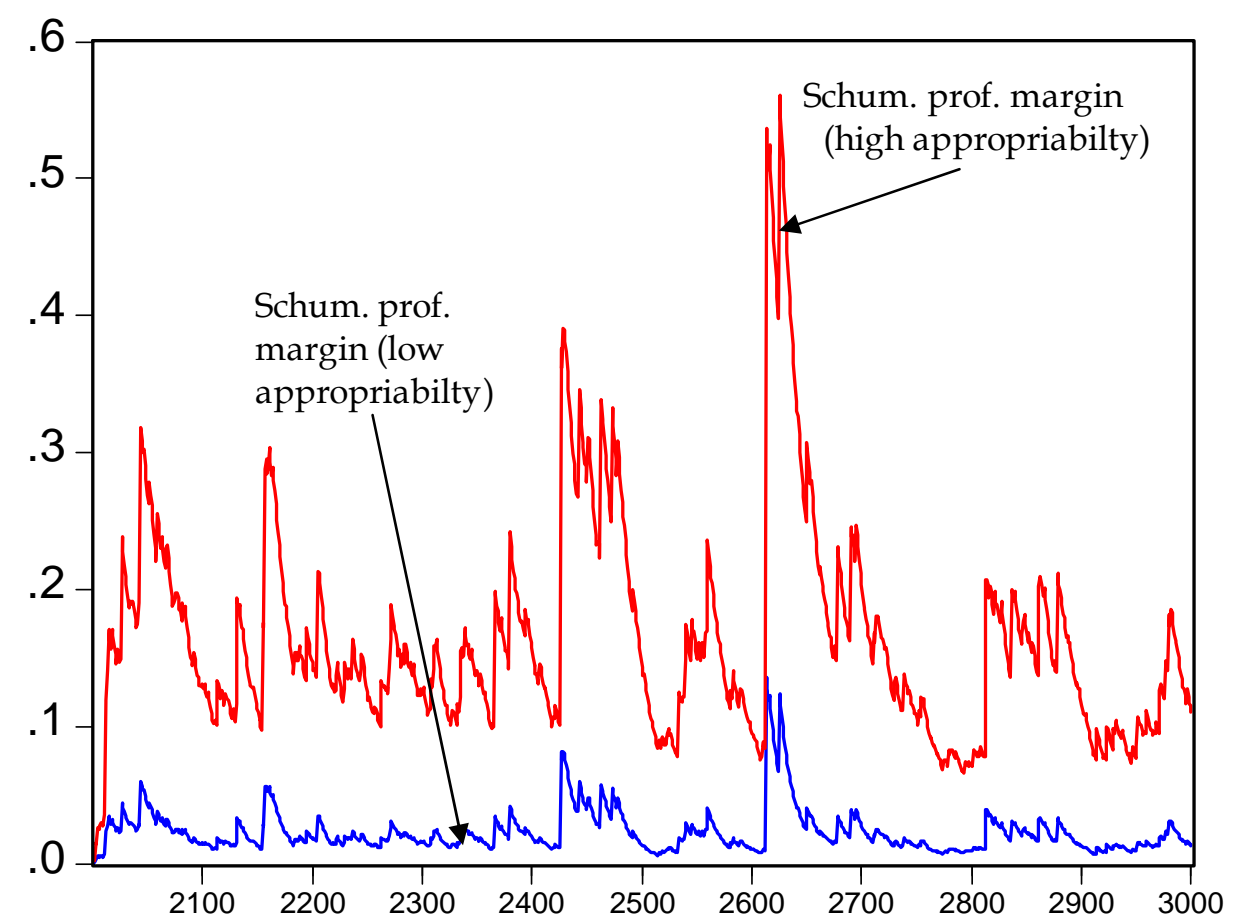

Figure 5. Schumpeterian margins with high and low appropriability $(\mathrm{n}=$ 1000) 


\section{A Macroeconomic Estimate of Schumpeterian Profits}

This section provides estimates of the importance of Schumpeterian profits for the nonfarm business sector (the farm sector is excluded because land values are such a large fraction of total capital in that sector). The basic calculation is the impact of multifactor productivity (MFP) growth on capital income. In addition, I will show that the results are insensitive to whether the variable is multifactor productivity or labor productivity. The data are prepared by the Bureau of Labor Statistics (BLS) for their calculations of multifactor productivity. The analysis here primarily uses a margin defined as total property income divided by total costs ( $m 1$ ). This margin is available from the BLS data and has relatively few conceptual difficulties. ${ }^{7}$

We should note that the theory applies to all innovations, domestic and foreign. In practice, the technique used here can only estimate appropriability for individual firms or countries. In this study, for example, we estimate the impact of multifactor productivity growth in the United States on innovational profits in the United States. Since there are both spill-outs to the international economy from domestic innovation as well as spill-ins to the U.S. economy from foreign innovations, our estimates are likely to be distorted. The direction of the distortion is difficult to determine, however, because the procedure is likely to overestimate the appropriability of domestic innovations (because some productivity impacts occur abroad) and underestimate

${ }^{7}$ All data are available at http://www.bls.gov/web/prod3.supp.toc.htm. 
domestic appropriability because of foreign innovations (which affect productivity but will not affect domestic profits).

For this purpose, we estimate eight different specifications. These are annual data and decadal data; a linear equilibrium relationship and a non-linear equilibrium relationship; and in level and first difference. The linear equation takes the following form:

$$
\mu(t)=r_{0}+r_{1} h(t)+\varepsilon(t)
$$

where $\mu(t)$ is the Schumpeterian profit margin, $h(t)$ is the rate of growth of multifactor productivity, $\varepsilon(t)$ is a random disturbance, and $\gamma_{0}$ and $\gamma_{1}$ are estimated coefficients.

In equation (8), to determine the appropriability parameter, we take the derivative of $\mu$ with respect to $h$, which yields:

$$
d \mu / d h=a h^{*} /\left(\lambda-h^{*}\right)^{2}
$$

from which we derive

$$
a=[d \mu / d h]\left(\lambda-h^{*}\right)^{2} / h^{*}
$$

where $[d \mu / d h]$ is the regression coefficient, $\lambda$ is set a priori at 0.2 , and $h^{*}$ is the mean of the sample for $h$.

(9) $d \mu / d h=a h^{*} /\left(\lambda-h^{*}\right)^{2}$ 
The non-linear specification takes the following form, which estimates the appropriability coefficient directly conditional on the depreciation rate:

$$
\mu(t)=\gamma_{0}+a\left\{h^{*} /\left(\lambda-h^{*}\right)\right\}+\varepsilon(t)
$$

The results of these estimates for the non-farm business sector are shown in Table 1. The overall estimates are quite consistent for the different specifications and show an appropriability factor of between 5 percent and 10 percent for the non-farm business sector. Standard errors are consistently estimated only for the third and fourth rows, but these show quite well determined coefficients, with standard errors in the order of 1.5 percentage points.

Figure 6 shows a plot of the left- and right-hand sides of equation (9). The dots are the data for1949-2001, while the line shows the equilibrium relationship between productivity and the gross margin that would be consistent with an appropriability factor of 5 percent.

There is no consensus on the appropriate depreciation rate for $R \& D$, with estimates ranging from 10 to 25 percent per year. The calculations in Table 1 assume a depreciation rate of 20 percent per year, which is consistent with data from patent renewals. ${ }^{8}$ It has not been

\footnotetext{
8 See Ariel Pakes and Margaret Simpson, "Patent Renewal Data," Brookings Papers on Economic Activity, Microeconomics, 1989, pp. 331-410 and the references therein. Estimates of the depreciation rate for patent renewals are higher than the numbers in the literature on the returns to research and development (which cluster around 15 percent per year). However, the latter generally refer to social rather than private depreciation, and the private rate would generally exceed the social rate due to erosion of market
} 
possible with the macroeconomic data to estimate the appropriability ratio and the deprecation rate jointly. However, the first set of four columns in Table 2 shows estimated values of the appropriability ratio conditional on different depreciation rates. The appropriability ratios are clearly sensitive to the depreciation assumption. The Schumpeterian profit margins are much less sensitive, however, as is shown in the last set of four columns in Table 2. The average value of the Schumpeterian margin across the eight specifications varies from a high of 0.55 percent for the lowest depreciation rate to a high of 0.58 for the highest depreciation rate.

The appropriability applies only to the first year of an innovation. After the first year, the appropriability depreciates over time because of imitation and loss of market power. Figure 7 shows the time path of appropriability for the first estimate in Table 1 and for two alternative depreciation rates. Lower depreciation rates lead to lower initial appropriability ratios than those calculated with higher depreciation rates, but this ranking is reversed through depreciation after a few years.

Additionally, we attempted to estimate the dynamic specification in equation (7) above. The results were uniformly unsatisfactory, with negative depreciation factors and wildly differing appropriability factors. The difficulty is apparently the cyclical nature of productivity and profitability, which yields a spurious relationship between the two series that is not related to underlying trend multifactor productivity. Given

position of the innovator. (See Bronwyn H. Hall, "Industrial Research during the 1980s: Did the Rate of Return Fall?" Brookings Papers on Economic Activity, Microeconomics, 1993, pp. 289-343.) 
the difficulties in capturing the dynamic specification, it is dropped for the balance of this study.

It is useful to determine how sensitive the estimates are to the measure of productivity that is used. The second column of Table 3 shows estimates of the appropriability ratio where we substitute BLS's measure of labor productivity for multifactor productivity. A comparison of these estimates with those from Table 1, shown for convenience in the first column of Table 3, indicate essentially the same estimates. Also (not shown), the standard errors of the coefficients are very similar to those in Table 1.

Figure 8 shows the importance of estimated Schumpeterian profits in total corporate profits over the 1948-2001 period. The estimated share varied from a low of -1.3 percent to a high of 6.3 percent of corporate profits (the negative number arises because of negative measured MFP growth for several years in the 1974-82 period).

Finally, we can estimate the overall appropriability of innovation using both the appropriability coefficient and the depreciation rate. The central estimates of these two parameters are 0.07 and 0.20 . If we combine these estimates with a growth rate of the economy of 3 percent per year and a discount rate on Schumpeterian profits of 10 percent per year, this implies that 2.2 percent of the total present value of social returns to innovation are captured by innovators. The highest and lowest present value of that ratio from all the estimates in Tables 1 and 2 are 1.3 percent and 3.3 percent. 


\begin{tabular}{|c|c|c|c|c|c|}
\hline \multirow[b]{2}{*}{ Sector and method } & \multicolumn{2}{|c|}{$\begin{array}{l}\text { Regression } \\
\text { Coefficients }\end{array}$} & \multicolumn{2}{|c|}{$\begin{array}{l}\text { Appropriability } \\
\text { Ratio [a] }\end{array}$} & \multirow{2}{*}{$\begin{array}{c}\text { Equilibrium Share } \\
\text { of Schumpeterian } \\
\text { Profits } \\
\begin{array}{c}\text { Percent of total } \\
\text { output] }\end{array} \\
\end{array}$} \\
\hline & $\begin{array}{c}\text { Coeff- } \\
\text { icient }\end{array}$ & $\begin{array}{c}\text { Standard } \\
\text { error of } \\
\text { coefficient }\end{array}$ & $\begin{array}{l}\text { Coef- } \\
\text { ficient }\end{array}$ & $\begin{array}{r}\text { Standar } \\
\mathrm{d} \text { error }\end{array}$ & \\
\hline \multicolumn{6}{|l|}{$\begin{array}{l}\text { Equilibrium: Annual } \\
\text { Linear equilibrium }\end{array}$} \\
\hline Level +AR & 0.391 & 0.090 & $7.8 \%$ & $1.8 \%[b]$ & $0.55 \%$ \\
\hline $\begin{array}{c}\text { Difference } \\
\text { Non-linear equilibrium }\end{array}$ & 0.376 & 0.083 & $7.5 \%$ & $1.7 \%[b]$ & $0.53 \%$ \\
\hline Level +AR & 0.062 & 0.015 & $6.2 \%$ & $1.5 \%$ & $0.44 \%$ \\
\hline Difference & 0.059 & 0.014 & $5.9 \%$ & $1.4 \%$ & $0.42 \%$ \\
\hline $\begin{array}{l}\text { Equilibrium: Decadal }[\mathrm{d}] \\
\text { Linear equilibrium }\end{array}$ & \multicolumn{4}{|c|}{ Equilibrium: Decadal [d] } & \\
\hline Level +AR & 0.521 & 0.134 & $10.4 \%$ & $2.7 \%[b]$ & $0.74 \%$ \\
\hline Difference & 0.522 & 0.129 & $10.4 \%$ & $2.6 \%[b]$ & $0.74 \%$ \\
\hline Non-linear equilibrium & & & & & \\
\hline Level +AR & 0.092 & 0.023 & $9.2 \%$ & $2.3 \%[c]$ & $0.65 \%$ \\
\hline Difference & 0.091 & 0.022 & $9.1 \%$ & $2.2 \%[c]$ & $0.64 \%$ \\
\hline
\end{tabular}

[a] All estimates assume the depreciation rate is 20 percent per year (exponential).

[b] These standard errors take the standard errors and scale them proportionally for the ratio of the appropriability coefficient to the regression coefficient.

[c] These standard errors are inconsistent because the samples overlap.

[d] The decadal estimates take 10-year averages of margins and total factor productivity growth.

Notes on regression equations:

The linear equilibrium estimates are equations of the following form:

$$
\mu(t)=\gamma 0+\gamma 1 h(t)+\varepsilon(t)
$$

where

$$
a=\gamma 1\left(\lambda-h^{*}\right) 2 / h^{*}
$$

The (lambda $=0.2)$ equilibrium estimates are

$$
\mu(t)=\gamma 0+a\{h(t) /[\lambda-h(t)]\}+\varepsilon(t)
$$

Table 1. Results for the non-farm business sector 


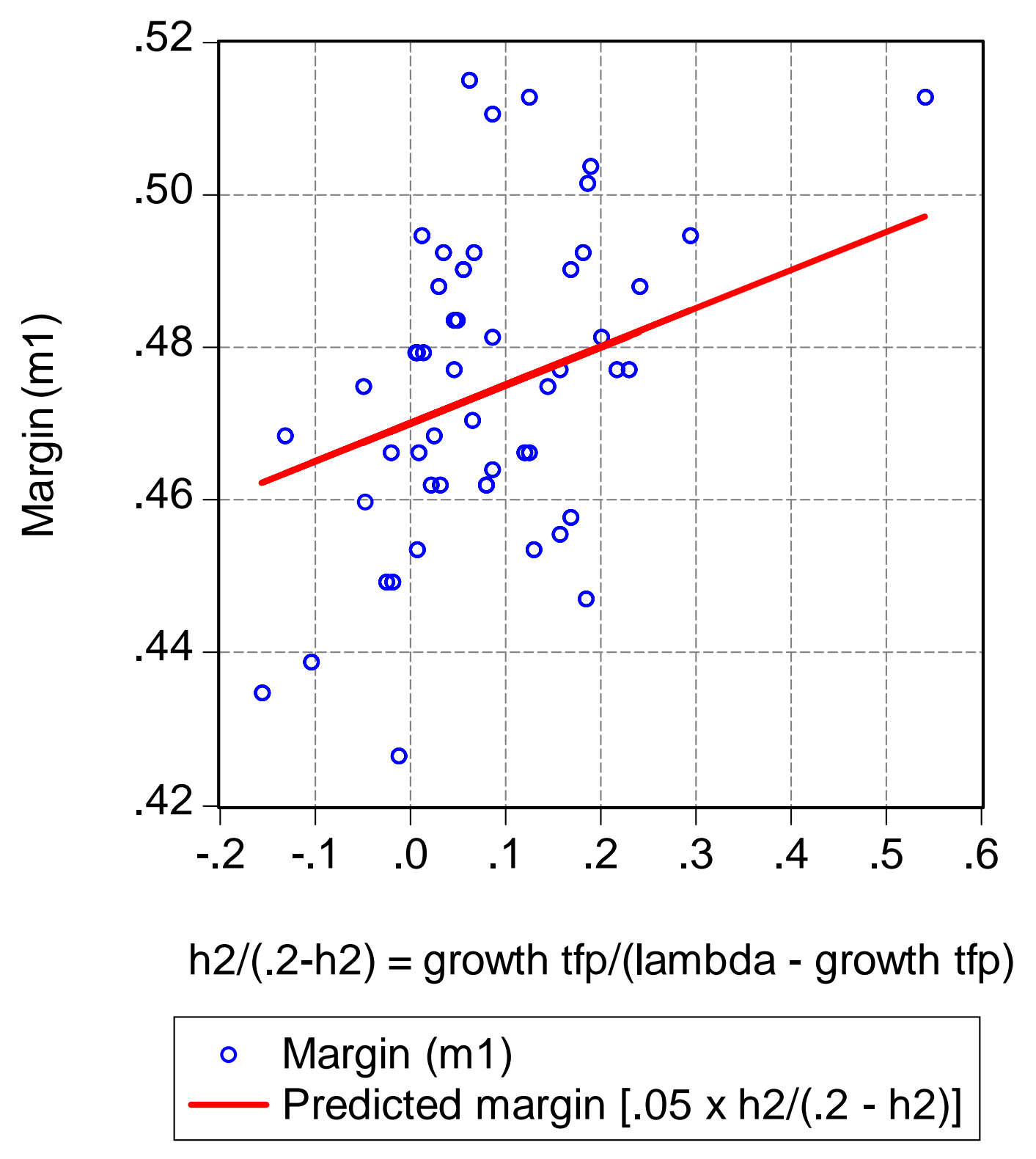

Figure 6. Relationship between productivity growth and the gross margin for private business sector.

Horizontal axis is the right hand side of equation (6) for the business sector over the period 1949-2002 while the vertical axis is the Schumpeterian margin. The slope is estimated to be 0.059 , which is the estimated appropriability ratio. Using these estimates, the share of Schumpeterian profits is estimated to be 0.037 percent of total output. 


\begin{tabular}{|c|c|c|c|c|c|c|c|c|}
\hline \multirow[b]{2}{*}{ Sector and method } & \multicolumn{4}{|c|}{$\begin{array}{l}\text { Appropriability } \\
\text { Ratio }\end{array}$} & \multicolumn{4}{|c|}{$\begin{array}{c}\text { Equilibrium Share } \\
\text { of Schumpeterian } \\
\text { Profits }\end{array}$} \\
\hline & $\begin{array}{l}\lambda= \\
0.1\end{array}$ & $\begin{array}{l}\lambda= \\
0.2\end{array}$ & $\begin{array}{l}\lambda= \\
0.3\end{array}$ & $\begin{array}{l}\lambda= \\
0.4\end{array}$ & $\begin{array}{l}\lambda= \\
0.1\end{array}$ & $\begin{array}{l}\lambda= \\
0.2\end{array}$ & $\begin{array}{l}\lambda= \\
0.3\end{array}$ & $\begin{array}{l}\lambda= \\
0.4\end{array}$ \\
\hline \multicolumn{9}{|l|}{$\begin{array}{l}\text { Equilibrium: Annual } \\
\text { Linear equilibrium }\end{array}$} \\
\hline Level +AR & $3.9 \%$ & $7.8 \%$ & $11.7 \%$ & $15.7 \%$ & $0.60 \%$ & $0.55 \%$ & $0.54 \%$ & $0.53 \%$ \\
\hline Difference & $3.8 \%$ & $7.5 \%$ & $11.3 \%$ & $15.0 \%$ & $0.57 \%$ & $0.53 \%$ & $0.52 \%$ & $0.51 \%$ \\
\hline Non-linear equilibrium & & & & & & & & \\
\hline Level +AR & $1.6 \%$ & $6.2 \%$ & $10.3 \%$ & $14.3 \%$ & $0.24 \%$ & $0.44 \%$ & $0.47 \%$ & $0.49 \%$ \\
\hline Difference & $1.5 \%$ & $5.9 \%$ & $9.9 \%$ & $13.7 \%$ & $0.22 \%$ & $0.42 \%$ & $0.45 \%$ & $0.47 \%$ \\
\hline \multicolumn{9}{|l|}{$\begin{array}{l}\text { Equilibrium: Decadal } \\
\text { Linear equilibrium }\end{array}$} \\
\hline Level +AR & $5.2 \%$ & $10.4 \%$ & $15.6 \%$ & $20.8 \%$ & $0.79 \%$ & $0.74 \%$ & $0.72 \%$ & $0.71 \%$ \\
\hline Difference & $5.2 \%$ & $10.4 \%$ & $15.7 \%$ & $20.9 \%$ & $0.79 \%$ & $0.74 \%$ & $0.72 \%$ & $0.71 \%$ \\
\hline Non-linear equilibrium & & & & & & & & \\
\hline Level +AR & $3.9 \%$ & $9.2 \%$ & $14.4 \%$ & $19.6 \%$ & $0.60 \%$ & $0.65 \%$ & $0.66 \%$ & $0.67 \%$ \\
\hline Difference & $3.9 \%$ & $9.1 \%$ & $14.2 \%$ & $19.4 \%$ & $0.59 \%$ & $0.64 \%$ & $0.65 \%$ & $0.66 \%$ \\
\hline
\end{tabular}

Table 2. Appropriability ratios and Schumpeterian profit margins for different discount rates 


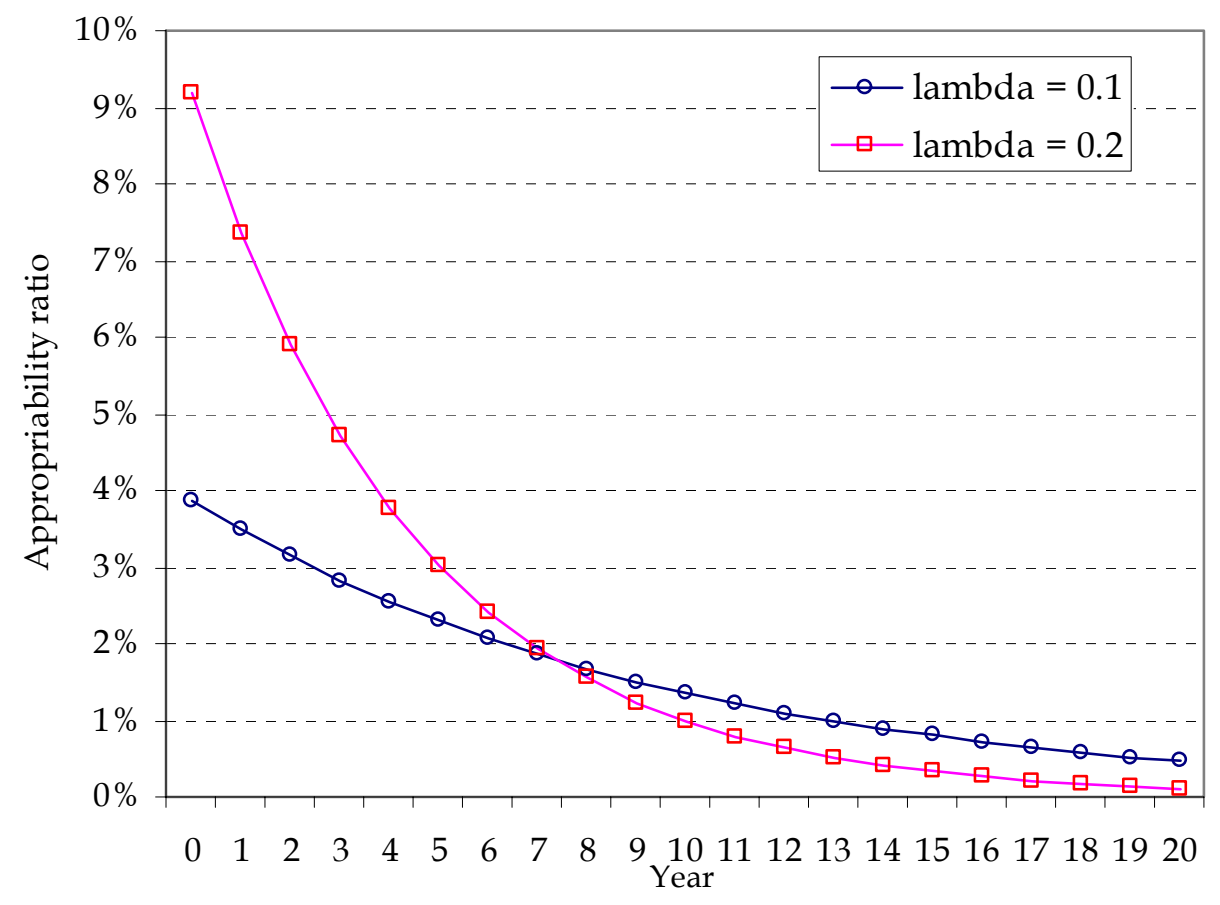

Figure 7. Appropriability for Different Depreciation Rates

This figure shows the appropriability factor for an innovation as a function of the appropriability ratio and the time since the innovation. The two curves are for the two different depreciation rates as shown in Table 2. 


\begin{tabular}{|c|c|c|}
\hline \multirow[b]{2}{*}{ Sector and method } & \multicolumn{2}{|c|}{$\begin{array}{c}\text { Appropriability } \\
\text { Ratio }\end{array}$} \\
\hline & Table 1 & $\begin{array}{l}\text { Labor } \\
\text { productivity }\end{array}$ \\
\hline \multicolumn{3}{|l|}{$\begin{array}{l}\text { Equilibrium: Annual } \\
\text { Linear equilibrium }\end{array}$} \\
\hline \begin{tabular}{|l} 
Level +AR \\
\end{tabular} & 0.078 & 0.073 \\
\hline Difference & 0.075 & 0.070 \\
\hline Non-linear equilibrium & & \\
\hline Level +AR & 0.062 & 0.046 \\
\hline Difference & 0.059 & 0.043 \\
\hline \multicolumn{3}{|l|}{$\begin{array}{l}\text { Equilibrium: Decadal } \\
\text { Linear equilibrium }\end{array}$} \\
\hline Level +AR & 0.104 & 0.121 \\
\hline Difference & 0.104 & 0.121 \\
\hline Non-linear equilibrium & & \\
\hline Level +AR & 0.092 & 0.094 \\
\hline Difference & 0.091 & 0.091 \\
\hline
\end{tabular}

Note: Table shows the estimated appropriability ratio for three different specifications: column (1) is the main specification shown in Table 1 Column (2) is identical to column (1) except that the productivity concept is output per hour worked.

Table 3. Appropriability ratios for different specifications 


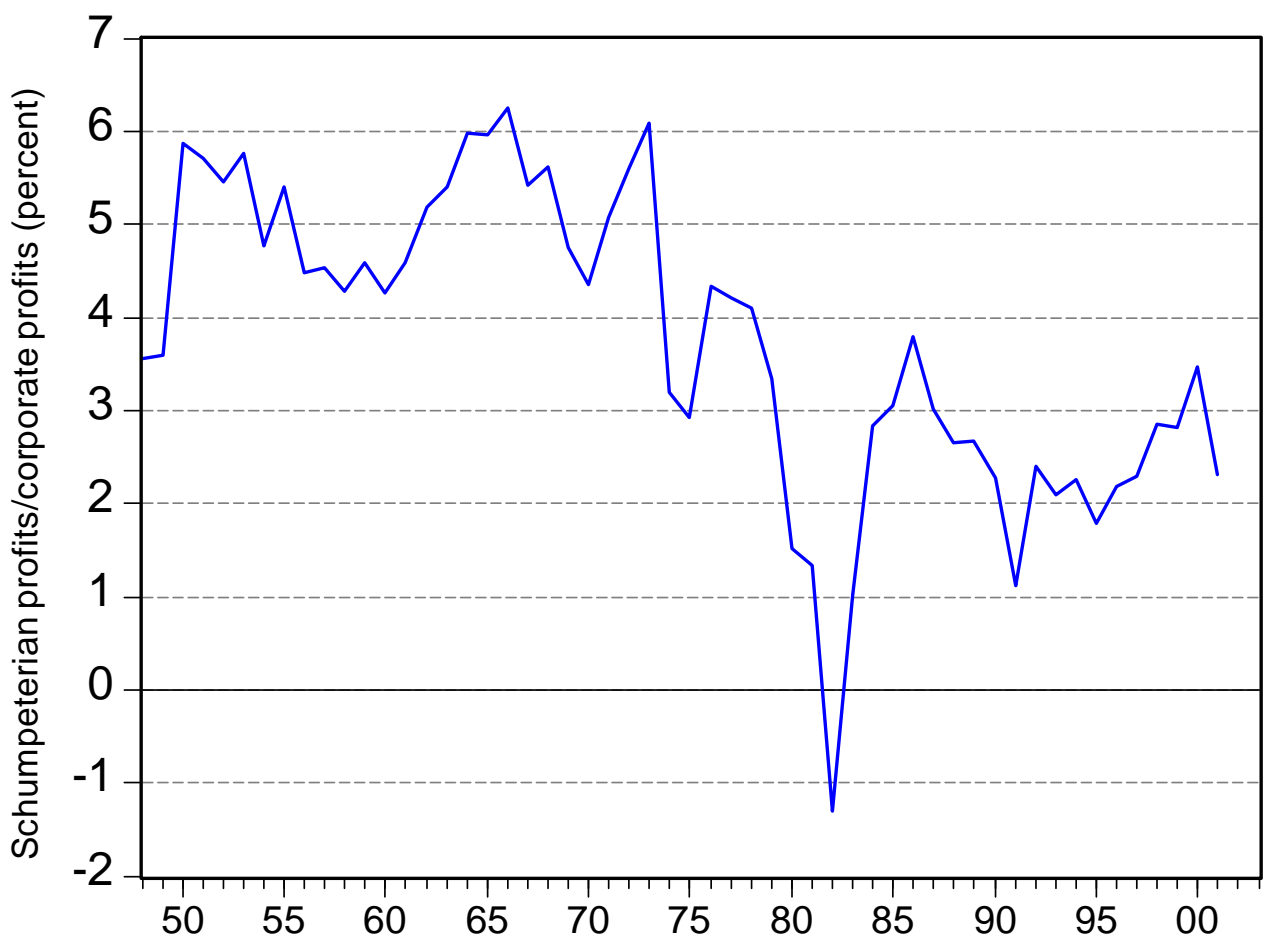

Figure 8. Schumpeterian profits as percent of total corporate profits This figure shows total Schumpeterian profits in the non-farm business sector as percent of total corporate profits. These are calculated by applying the estimated parameters to BLS's estimate of multifactor productivity growth. Estimated Schumpeterian profits were 3.8 percent of total profits over the 1948 - 2001 period. 


\section{Implications for Profits and Wealth}

In this section, we consider the implications of this analysis for the stock market and for the "Greenspan effect."

\section{A. Schumpeterian profits and the stock market}

In the late 1990s, the stock market rose sharply, particularly in the "new economy" sectors of computers, software, and communications. There were many reasons put forth for the dramatic rise, but many analysts pointed to the impact of rapid technological change on profits and stock values. To put this in the language of this study, if the rapid growth in innovation has led to an accompanying rapid growth in Schumpeterian profits, then the present value of future profits would rise sharply.

To put this quantitatively, consider the following example: The new economy amounts to 5 percent of nominal output. Up to an initial period (1995?), productivity is perceived to be growing at the same rate as in other sectors. Then, a rapid acceleration of productivity growth occurs. In the new world, costless multifactor productivity growth is 15 percent per year. Assuming total output is $\$ 10$ trillion in the initial year, the new economy would be adding about $\$ 75$ billion per year per year in social surplus in the initial year. If the new entrepreneurs could capture 90 percent of the new economy surplus in Schumpeterian profits with low depreciation, then with other plausible parameters, the increase in 
value of new economy firms would be $\$ 5.8$ trillion. ${ }^{9}$ This is close to the increase in value of new economy firms from 1995 to 2000.

The problem with this scenario, however, is that the likelihood of new economy entrepreneurs capturing half of the social surplus is vanishingly small. One reason for doubting a high appropriability is, as shown by the results in this study, that U.S. capitalism grinds Schumpeterian profits into such a fine powder that they can barely be detected in the macroeconomic. If the new economy entrepreneurs could capture 7 percent of the social gains - which is a good guess based on our estimates - then under the assumptions above the increase in the market value of the excess profits from the productivity acceleration would be $\$ 410$ billion rather than to $\$ 5.8$ trillion. (This $\$ 410$ billion would, of course, be in excess to the normal return to capital and intangible investments.)

A second reason to be skeptical of high Schumpeterian profits in the new economy is because of the nature of the industry. With a few exceptions, entry and exit is relatively easy; the rapidity of the entry and easy demise of new economy firms indicates not only that bright ideas could get easily funded but also, alas, that imitators are quick to follow.

\footnotetext{
${ }^{9}$ The assumptions behind this are the following: I assume that the new economy is 5 percent of a $\$ 10$ trillion economy; that the new economy is growing at 6 percent per year in real terms (in nominal values deflated by the GDP price index) for the first 20 years, then at 3 percent after that; that entrepreneurs appropriate half of the social value of technological change; that the rate of costless technological change is 15 percent per year; and that the real discount rate on earnings is 10 percent per year. Under these assumptions, the present value of new economy earnings is $\$ 7.2$ trillion when discounting the profits for the first 50 years, which is $\$ 5.8$ trillion more than the value would be if the new economy had the same parameters as the old economy.
} 
One way that the high entry and exit will affect Schumpeterian profits is through the depreciation rate, which is likely to be very high in neweconomy sectors. Etoys.com sounded like a great idea for toys; but ToysR-Us had more savvy and toys and could easily and quickly adopt the bright ideas of the first movers. In reality, both are bankrupt today. While we have incomplete information on the aggregate profits of neweconomy firms, it appears that at the peak of the cycle in 2000, profits in this industry were actually negative. ${ }^{10}$

A third reason to doubt the presence of large Schumpeterian profits is that the information revolution concerns information, which is generally hard to appropriate. The economic nature of information is that it is expensive to produce and inexpensive to reproduce. Indeed, with the Internet, it is often essentially free to reproduce and distribute vast amounts of information. The low costs of imitation, transmission, and distribution of information technologies are likely to erode the value of property rights in intellectual property and reduce the durability of Schumpeterian profits in the new economy. An illustrative case is the appropriability of the value of knowledge embedded in encyclopedias. To imitate the Encyclopedia Britannica two decades ago would have required a massive investment in recruiting of scholars and editors along with a major publishing effort. Today, an online or CD encyclopedia is extremely inexpensive to produce and distribute, and some are free to

10 The Bureau of Economic Analysis publishes corporate profits by industry for three new economy industries using the new industrial classification system (NAIQS) for the period 1998-2002: Computer and electronic products, Electrical equipment, appliances, and components, and Information. Profits for these industries was $\$-8$ billion in 2000 and was negative for every year thereafter. (Data are from Table 6.16D in the NIPA tables at www.bea.gov.) 
consumers, such as Microsoft's online Encarta. Indeed, the Internet is itself a gigantic free encyclopedia.

\section{B. The Greenspan Effect}

In the late 1990s, productivity and the economy were growing rapidly, and some economists wondered whether there was a linkage through the stock market. Just such an effect was suggested by Federal Reserve Chairman Alan Greenspan:

Productivity-driven supply growth has, by raising long-term profit expectations, engendered a huge gain in equity prices. Through the so-called "wealth effect," these gains have tended to foster increases in aggregate demand beyond the increases in supply....

[In] recent years, largely as a result of the appreciating values of ownership claims on the capital stock, themselves a consequence, at least in part, of accelerating productivity, the net worth of households has expanded dramatically, relative to income. This has spurred private consumption to rise even faster than the incomes engendered by the productivity-driven rise in output growth. ${ }^{11}$

I define the Greenspan effect as the impact of rising productivity on aggregate demand through the wealth effect on consumption. Chairman Greenspan suggests not only that the impact is positive, but also that it is larger than the impact on aggregate supply.

11 Remarks by Chairman Alan Greenspan, "Technology and the economy," Before the Economic Club of New York, New York, New York, January 13, 2000 at http:// www.federalreserve.gov/boarddocs/speeches/2000/200001132.ht $\mathrm{m}$. 
The estimates provided here allow an estimate of the size of the Greenspan effect operating through private consumption. For this purpose, assume that all of output is produced in publicly owned corporations and that all productivity growth is driven by domestic innovation. From these, we deduce following from the model in section I. The current value of Schumpeterian profits as a fraction of corporate output is $\mathrm{V}=a h^{*} /\left(\lambda-h^{*}\right)$, and the value of equities is the discounted value of that. Suppose that economy-wide productivity rises permanently by $\Delta h^{*}$ percent per year. Further, assume that the marginal propensity to consume out of wealth is $w$. Using the empirical estimates from section II ( $a=.07$ with $\lambda=0.2)$ and these assumptions, the ratio of the present value of Schumpeterian profits to corporate output is 4.8 percent when productivity growth is 1 percent per year, while that ratio is 10.8 percent with productivity growth of 2 percent per year. Using the value of $w$ of 0.04 , the increase in consumption from an unanticipated increase in productivity growth by 1 percentage point is $.04 \times(.108-.048)$ $=0.24$ percent of total output. ${ }^{12}$

Hence for the estimated value of the parameters, an unanticipated 1 percent increase in multifactor productivity that is driven entirely by appropriable innovation will lead in the first year to a 1 percent increase

\footnotetext{
12 The calculation becomes more complicated if we correct for the fact that the corporate output is only about 60 percent of total GDP and that only part of the return to capital is earned by public corporations. If all MFP growth in confined to public corporations, then the numbers in the text will all be scaled down by the ratio of the output of public corporations to GDP but the ratio, 0.24 , will be unchanged. If some of MFP growth occurs outside of public corporations, then the ratio would be smaller to the extent that business owners are constrained from consuming according to the underlying consumption model.
} 
in potential output and a 0.24 percentage point increase in consumption. This calculation suggests that the Greenspan effect on aggregate demand through consumption is about one-quarter of the effect on potential output, and that this impact of productivity growth through the Greenspan effect is not inflationary.

\section{Conclusion}

The present study develops a technique for estimating the size of Schumpeterian profits in a market economy. It shows that innovational profits depend upon the appropriability of innovations as well as the rate of depreciation of profits from the innovations. Using data from the U.S. nonfarm business section, I estimate that innovators are able to capture about 2.2 percent of the total social surplus from innovation. This number results from a low rate of initial appropriability (estimated to be around 7 percent) along with a high rate of depreciation of Schumpeterian profits (judged to be around 20 percent per year). In terms of the rate of profit on capital, the rate of profit on the replacement cost of capital over the 1948-2001 period is estimated to be 0.19 percent per year.

One reaction to these numbers is that the rate of Schumpeterian profits is implausibly low given the enormous innovativeness of the American economy. Another reaction is that it clears up at least part of a puzzle about the profitability of American capitalism. Some observers have wondered why the rate of profit on corporate capital is so low. Indeed, over the last four decades in which we have careful measurement, the rate of profit after tax on nonfinancial corporations 
averaged 5.9 percent per year, which was very close to the cost of capital over that period. How could the rate of profit be so low, it might be asked, given that the denominator omits several important assets (such as land and intangible investments) and the numerator includes important sources of profits (such as monopoly power and Schumpeterian profits)? At least part of this puzzle is resolved here by the finding that only 20 basis points of the rate of return to capital was due to Schumpeterian profits. 